\title{
Combined Vital Dye Labelling and Catecholamine Histofluorescence of Transplanted Ciliary Ganglion Cells
}

\author{
John Sechrist, James N. Coulombe, and Marianne Bronner-Fraser \\ Developmental Biology Center, University of California \\ Irvine, Ca. 92717, USA.
}

\section{SUMMARY}

We have utilized the carbocyanine dye, DiI, to label suspensions of dissociated ciliary ganglion cells removed from 6 to 12 day old quail embryos. Some of the cells were injected into the trunk somites of 2.5 - 3 day old chick embryos along pathways where neural crest cells migrate to form sensory and sympathetic ganglia, aortic plexuses and the adrenal medulla; the remainder of the cells were cultured to check their viability and the persistence of the DiI label. Embryos were incubated for 1 - 8 days post-injection, fixed in $4 \%$ paraformaldehyde $/ 0.25 \%$ glutaraldehyde and processed for cryostat sectioning. DiI-labelled cells were readily identifiable in culture and in sections of embryos at all stages examined. Several cell types were identified, based on their morphology and soma size. These included cells with large cell bodies and bright DiI-labelling that appeared to be neurons and smaller, more weakly labelled cells that appeared non-neuronal. The latter presumably had divided several times, accounting for their reduced levels of dye. Many of the DiI-labelled cells were found in and around neural crest-

Reprint address:

John Sechrist

Developmental Biology Center

University of California

Irvine, CA 902717, USA derived sympathetic ganglia, aortic plexuses and adrenomedullary cords, but were rarely observed in dorsal root ganglia. The aldehyde fixative (Faglu mixture) used in this study reacts with catecholamines to form a bright reaction product in adrenergic cells including those in the sympathetic ganglia and the adrenal medulla. The catecholamine biproduct and the DiI in the same cell can easily be viewed with different fluorescent filter sets. A variable number of the DiI-labelled cells in these adrenergic sites contained catecholamines. Cells derived from younger 6 day ciliary ganglion dissociates exhibited detectable catecholamine neurotransmitters earlier and more frequently than those derived from 8 day embryos. The presence of cells exhibiting both bright DiI and catecholamine fluorescence is consistent with previous indications that post-mitotic ciliary ganglion neurons can undergo phenotypic conversion from cholinergic to adrenergic when transplanted to the trunk environment.

\section{INTRODUCTION}

A central question in developmental neurobiology is how a complex nervous system develops from the relatively homogeneous group of precursor cells within the neural plate. Cells in the developing nervous system undergo extensive proliferation, migration and reorganization. 
During morphogenesis they differentiate into a wide variety of neurons and neuronal support cells. Although little is known about the factors that influence their differentiation, it is likely that both inherent lineage information and environmental cues play important roles /33/. One way to examine the role of environmental cues in directing neuronal differentiation is to transplant neurons to ectopic sites and examine their subsequent phenotypic expression.

We have been examining the ability of cholinergic neurons to change their neurotransmitter in response to their surroundings. Three basic criteria are important for successful evaluation of transmitter plasticity following neural transplantation. First, the labelling and transplantation procedures must be conducive to neuronal survival. Second, grafted cells and their processes should be readily distinguishable within host structures in order to analyze their degree of integration. Third, it should be possible to identify the neurotransmitter(s) produced by the grafted cells.

In our studies of phenotypic plasticity in the autonomic nervous system, we have shown that retrogradely labelled ciliary neurons survive transplantation into the trunk region of chick embryos when microinjected as a cell suspension. Some of these neurons, which were cholinergic at the time of transplantation, migrated to "adrenergic sites" and developed catecholamine fluorescence by 4 - 5 days /4/. This finding contrasts with those of LeDouarin and colleagues, who implanted pieces of ciliary ganglia into this same region $/ 7,21,23 /$ and found that non-neuronal cells survived whereas post-mitotic neurons soon died $/ 7 /$.

We have found it necessary to utilize new approaches for identifying transplanted cells and analyzing their differentiation. In the present study, we describe the application of a vital dye marking technique, using DiI (1,1-dioctadecyl3,3,3',3'-tetramethylindocarbocyanine perchlorate), for labelling dissociated quail ciliary ganglion cells for transplantation into the trunk region of chick embryos. The fixation procedure adapted for preserving dye labelled cells utilizes an aldehyde mixture which is similar to a previously described formaldehyde/glutaraldehyde (Faglu) method /12/ for locating catecholamines by histofluorescence. This method, which provides excellent morphological preservation, allows us to identify the transplanted cells and assess their catecholamine content within the same section without further tissue processing. In agreement with previous studies, our results show that ciliary ganglion cells can acquire catecholamines after grafting into young chick embryos $/ 4,21 /$. In addition, our data suggest that some previously conflicting conclusions regarding post-mitotic neuron survival may be due to differences in ganglionic age at the time of implantation.

\section{MATERIALS AND METHODS}

\section{Donor and Host Embryos}

Japanese quail and White Leghorn chick eggs were incubated at $38 \pm 1^{\circ} \mathrm{C}$. Six to nine day old quail embryos were used as donors for transplanted ciliary ganglion cells, whereas 2.5 - 3 day old chick embryos (stages 14 - 18), according to the criteria of Hamburger and Hamilton /13/, were used as hosts for the transplanted cells. For preparation of cultures, ciliary ganglia removed from 6 to 12 day old embryos were used.

\section{Ciliary Ganglion Dissociation}

Quail ciliary ganglia were dissociated as described previously /4/. Eyeballs with part of the optic nerve and adjacent ciliary ganglion were removed from the heads of 20 - 30 embryos with fine forceps and iridectomy scissors. They were then placed into Modified Puck's Saline with glucose (MPG) which is calcium and magnesium free. The ganglia were cleaned of loose connective tissue and nerve roots. The number of cells per ganglion varies from 10,000 to 20,000 between embryonic days 6-11/7/. The ganglia were dissociated in $0.1 \%$ trypsin (Gibco) in MPG for 20 minutes at $37^{\circ} \mathrm{C}$ and the reaction was stopped 
with culture media containing serum (see below), followed by a wash in fresh culture medium, and mechanical dissociation utilizing gentle trituration involving 20 or more passes of the ganglia through a fire-polished Pasteur pipet with a reduced bore size. For labelling with DiI (see below), the dye was added just prior to the trituration step.

\section{Cultures of Ciliary Ganglion Fragments and Dis- sociated Cells}

Dissociated ciliary ganglion cells or ganglionic fragments were grown in a culture medium consisting of $75 \%$ Minimum Essential Medium (Gibco), 15\% horse serum (Gibco) and 10\% embryo extract on tissue culture dishes coated with either fibronectin (New York Blood Bank) or laminin (Collaborative Research). The fibronectin and laminin substrates were prepared by incubating $35 \mathrm{~mm}$ petri dishes with $25 \mu \mathrm{g} / \mathrm{ml}$ and $15 \mu \mathrm{g} / \mathrm{ml}$ of fibronectin or laminin, respectively, prior to adding the cells. Suspensions of ciliary ganglion cells were prepared as described above and added to the matrix-coated dishes. Fragment cultures consisted of cutting the quail ganglia into several parts with iridectomy scissors following collagenase treatment, and then plating the ganglion pieces onto the substrates.

\section{Labelling with DiI}

A stock solution consisting of $0.5 \%$ (weight/volume) DiI in 100\% EtOH (Molecular Probes, Junction City, Oregon) analogous to that previously described for injecting Dil into the neural tube of chick embryos /31/ was utilized. After trypsinization and one wash of the ganglia with culture media, the DiI stock solution was diluted in culture media to yield a final dye concentration of approximately $100 \mu \mathrm{g} / \mathrm{ml}$. One to two $\mathrm{ml}$ of this dye solution was added to the washed ganglia in a test tube followed directly by trituration and $20 \mathrm{~min}$ incubation at $37^{\circ} \mathrm{C}$. The stained cells were then centrifuged $(1000 \mathrm{x}$ g) for $5 \mathrm{~min}$ and washed twice with culture media to remove excess dye. Each wash was followed by centrifugation with subsequent removal of supernatant. It is essential to wash the dissociated cells thoroughly in order to remove any DiI crystals from the cell suspension. The cells were then concentrated by centrifugation into a small volume of culture media to be used for microinjection.

\section{Host Preparation and Microinjection Techniques}

Chick eggs incubated for 2.5 days were washed with $70 \% \mathrm{EtOH}$. The shell over the embryo was covered with adhesive tape and a window was cut over the embryo. To aid visualization, an injection of India ink in culture media (1 part to 3 parts) was made under the blastoderm. The vitelline membrane was removed over the injection site. Labelled cells were introduced into selected somites (between somites 18 - 28) by using a previously described injection technique 12,3/. Briefly, some of the dyed cell suspension was backfilled into a micropipet (pulled from capillary tubing) with an opening of approximately 50 micrometers. The micropipet was mounted onto a micromanipulator (Narashige) and connected to a pressure injection apparatus. The manipulator was used to lower the micropipet to the embryonic surface and insert it into the somitic cavity, where the cells were expelled with a pulse of pressure. The labelled cells were deposited onto the ventral neural crest pathway along which move endogenous neural crest cell precursors to neurons, neuronal support cells, and adrenomedullary cells. A good injection included at least several hundred cells but the number varied considerably based on observations of the host embryo. After injection of the DiI-labelled cells, the window in the shell was closed with adhesive tape, and the eggs were returned to the incubator until the time of fixation. The present study utilized approximately 60 chick embryos, about half of which survived until the time of fixation and tissue processing.

\section{Histology and Catecholamine Fluorescence}

Host chick embryos were allowed to survive 
for 1 to 8 days after injection (corresponding to 3.5 to 10.5 days of total incubation time). Prior to fixation embryos were cut into several parts in avian Ringer's solution. The trunk region of the embryos was then fixed with an aldehyde mixture of $4 \%$ paraformaldehyde $/ 0.25 \%$ glutaraldehyde in $0.1 \mathrm{M}$ phosphate buffer at $\mathrm{pH} 7.4$ overnight at $4^{\circ} \mathrm{C}$. Glutaraldehyde was added because it fixes lipid membranes better than paraformaldehyde alone and therefore gives better preservation of DiI, which is lipid-soluble and hydrophobic /31/. After fixation, embryonic pieces were washed in $0.1 \mathrm{M}$ phosphate buffer ( $\mathrm{pH} 7.4$ ) for $1 \mathrm{hr}$, and prepared for cryostat sectioning by infiltrating with $5 \%$ and $15 \%$ sucrose in the same buffer for $4 \mathrm{hrs}-1$ day each at $4^{\circ} \mathrm{C}$. Larger embryos or parts required more time. The tissue was embedded in $7.5 \%$ gelatin in $15 \%$ sucrose solution for $2 \mathrm{hrs}$ at $37^{\circ} \mathrm{C}$ followed by rapid freezing in liquid nitrogen. Serial sections were cut at $10 \mu \mathrm{m}$ and mounted on subbed slides.

Slides were first observed without a coverslip and then stored at $4^{\circ} \mathrm{C}$. Gel mount (Biomedia Corp) and coverslips are recommended only for observation and photography within several hours after applying the coverslip because brightly stained cells do leak dye once covered with glass. Drying the sections on a slide without use of a coverslip actually appears to enhance catecholamine fluorescence (see below) and provides satisfactory morphology for low magnification photography. Sections were viewed and photographed with an Olympus epifluorescent microscope. Brightly DiI-labelled cells can be observed with either rhodamine or fluorescein filter sets, though the maximal signal is obtained through the former.

Catecholamine histofluorescence was primarily induced by fixing the tissue with a solution very similar to the original Faglu mixture /12/. The solution consists of the same ingredients used in fixing tissue containing DiI-labelled cells - paraformaldehyde (4\%), glutaraldehyde $(0.25 \%)$ and phosphate buffer ( $\mathrm{pH} 7.4)$. This differed from the original mixture in that the glutaraldehyde was $.5 \%$ and the $\mathrm{pH}$ was 7 but such a small variation was well within the optimum range for producing maximal fluorescence. In one case, a portion of an embryo was prepared for catecholamine histofluorescence using the glyoxylic acid method /6/ with the remainder fixed in the Faglu mixture. The Faglu method proved to be the easiest and most satisfactory for this study. After viewing Dil-labelling, the presence or absence of catecholamines was readily apparent by simply changing from the rhodamine to violet filter set.

To verify that the DiI-labelled cells were of quail origin, sections were incubated for $30 \mathrm{~min}$ with $2 \mu \mathrm{g} / \mathrm{ml}$ of 4-6-diamidino-2-phenylindole (DAPI) in Tris buffer at pH 7.4/22/. Since DAPI stains DNA in cell nuclei, it was possible to distinguish between quail nuclei, which contain prominent condensed heterochromatin /19/, and chick nuclei, which are comprised largely of euchromatin, by examining the sections under the ultraviolet filter set.

\section{RESULTS}

\section{Cultures of DiI-Labelled and Unlabelled Ciliary Ganglion Cells}

Prior to injecting labelled quail cells into chick embryos, we examined the morphology, behavior and viability of 6-12 day ciliary ganglion cells in tissue culture under a variety of conditions. Fragments of ciliary ganglia or dissociated ganglion cells were plated on either fibronectin or laminin and cultured for up to a week. The dissociation technique is based on earlier studies $/ 14,25,36 /$ which established conditions that optimized neuronal survival in tissue culture. Neurons are post-mitotic by embryonic day 6 in quail ciliary ganglion /7/; within 1 - 2 hours in culture they initiate axon regeneration whether clustered in fragments or dissociated. On laminin, the axons extend more rapidly and grow beyond the non-neuronal cells whereas, on fibronectin, processes initially remain close to the supporting cells.

In fragment culture on both substrata, the pieces of ganglia flatten, but the neuronal cell 
bodies tend to stay centrally aggregated with very little separation while the non-neuronal cells migrated freely. In cultures of dissociated cells, dispersed neurons grow well in the presence of supporting cells on either substrate for up to a week without addition of specific growth factors to our standard neural crest culture media. Typical cultures after 1 day on laminin are shown in Fig. 1a\&b; neurons derived from 12 day embryos are clearly larger than neurons derived from 6 day embryo with the exception of the smaller choroidal neurons (not shown). The younger neuronal somas average approximately $12 \mu \mathrm{m}$ in diameter whereas the older ones are closer to 20 $\mu \mathrm{m}$. Although the neurons are post-mitotic, many non-neuronal cells proliferate rapidly in our culture media.

The procedures described by Honig and Hume /15/ for labelling dissociated cells with DiI proved satisfactory for both culture and transplant studies. Application of the dye diluted in culture media to the ganglia just prior to dissociation appeared to have no detrimental effect on the behavior of subsequently cultured cells. Observations with the fluorescence microscope during the first several days in culture suggested that the dye was bound to the cell membrane and also was contained in small cytoplasmic granules (Fig. 1c). By the second or third day, much of the membrane staining including that of neuronal processes disappeared. The neurons still remained bright and could be recognized by their spherical cell soma in culture. The DiI-label in rapidly dividing cells diminished significantly after a week, but was still discernable. Following in vivo injection of labelled cells, the staining pattern of neuronal and non-neuronal cells sometimes remained similar to that observed in culture (Fig. 1d); however, the distinction between neurons and supporting cell types was typically obscured in sectioned tissue. This was particularly true of cells incorporated into a structure such as the sympathetic ganglia where neuroblasts are known to divide $/ 28,29 /$.
Appearance of Catecholamines in the Early Chick Embryo Using a Modified Formaldehydel Glutaraldehyde (Faglu) Method

Catecholamine fluorescence induced by the Faglu fixation method has two advantages for the analysis of catecholamines in transplanted cells. It provides a means of localizing DiI-labelled cells in relation to adrenergic trunk structures and also shows whether the DiI-labelled cell itself contains catecholamines. This technique /12/ for visualizing catecholamines circumvents the need for drying and heating of the tissue which are required in the better known glyoxylic acid /6/ and formaldehyde vapor /11/ methods of catecholamine histofluorescence.

In order to compare the modified Faglu method used in the present study with the glyoxylic acid method, one chick embryo was divided through the middle of the region containing DiI-labelled cells and each half of the trunk was processed differently: one by the glyoxylic acid method and the other by the Faglu method. In our experience with procedures combining the DiI and catecholamine techniques, the Faglu method provides for better morphological preservation and appears to be just as reliable for revealing most monoamines including norepinephrine $/ 12 /$.

Catecholamine containing cells can be identified beginning about embryonic day 3.5 in the chick. These are positioned dorsolateral to the dorsal aorta from where they soon begin to migrate to form definitive adrenergic structures such as sympathetic ganglia; their catecholamine content is primarily norepinephrine $/ 8 /$. Both the primary and migrating catecholamine containing cells are a heterogeneous population with regard to cell proliferation $/ 29 /$.

Distribution and Catecholamine Content of DiILabelled Ciliary Ganglion Cells After Microinjection

The extent to which DiI-labelled cells became incorporated into adrenergic structures after 

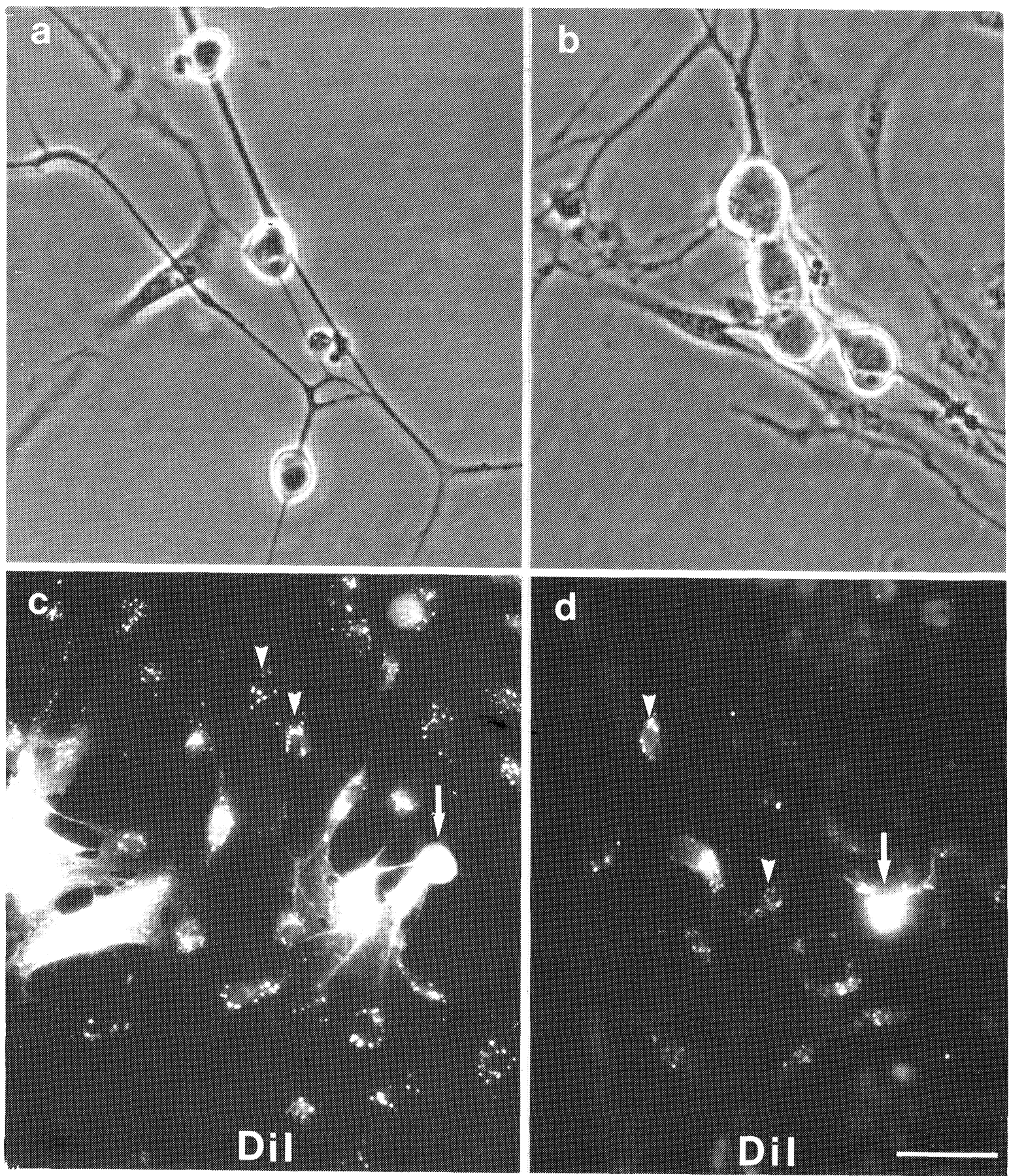

Fig. 1: Dissociated quail ciliary ganglia in cell culture (a-c) and after injection in vivo (d). a and b) Phase contrast views of embryonic 6 and 12 day ciliary ganglion dissociates after 1 day in culture on laminin; phase bright neurons enriched by preplating on fibronectin increase in size with age. c) Fluorescence view (rhodamine filter) of 12 day ciliary ganglion cell dissociate cultured on fibronectin for 1 day after Dil labelling. d) Fluorescence view of a transverse section through the ventral body wall 2 days after injection of an 8 day ciliary ganglion dissociate labelled with Dil. Both "in vitro" and "in vivo" examples show the dye may be bound in the cell membrane of bright neurons (arrows) and some non-neuronal cells or internalized in cytoplasmic granules (arrowheads) of both cell types; fewer granules and reduced brightness are characteristic of proliferating cells. Bar $=30 \mu \mathrm{m}$ in a \& b and $55 \mu$ in c \& d. 
transplantation and acquired catecholamines was examined in ciliary ganglion cells derived from 6 and 8 day old quail embryos. The 6 day time point was chosen to obtain neurons close to their time of final mitoses ( 4 - 5 days). Some of the ciliary ganglion cell transplants contained enough stained connective tissue debris to be visible through a dissecting microscope; this served to mark the injection site and was useful for orientation several days later.

1 Day After Cell Injection. Two embryos fixed at this stage were examined. Cells implanted into a somitic lumen are released onto the ventral neural crest pathway after dispersion of sclerotomal cells of the somite /3/. By the end of the first day of incubation, clusters of DiI-labelled cells were observed ventromedial to the dermamyotome and lateral to the notochord and dorsal aorta in the 3.5 day host (Fig. 2a). In sections rostral and caudal to the injection site, the Dil-labelled aggregates were smaller and were close to the notochord and ventral root nerve fibers. Few if any Dil-labelled cells extended ventral to the dorsal aorta at this time if injected properly.

By 3.5 - 4 days, the host primary sympathetic ganglia were forming dorsolateral to the aorta. They are segmental structures, and are not apparent in the section pictured in Fig. 2a; in adjacent sections, some cell clusters were observed close to the aorta which appeared to have low levels of catecholamine fluorescence. The DiIlabelled cells did not contain catecholamines at this stage.

2 - 3 Days After Cell Injection. Five host embryos were examined 2 or 3 days after transplantation. At both forelimb and mid-trunk levels in the 4.5 - 6 day host, Dil-labelled ciliary ganglion cells from both 6 and 8 day embryos were found in the dorsal mesentery below the aorta and even in the gut wall (Figs. 2b, 3a \& b). Some labelled cells remained dorsal to the aorta and a few were found in the somitic mesenchyme and nephrogenic mesoderm. They were particularly conspicuous in the region of the forming adrenal glands and sympathetic ganglia (Figs. 2c-e and 3).

By the fourth embryonic day the host adrenergic cells were easily identified due to their distinct catecholamine fluorescence. Some of the ciliary ganglion cell transplants derived from 6 day old embryos clearly showed catecholamine production and/or uptake (Figs. $2 \mathrm{~d} \&$ e and 3 ) in several sites along the ventral neural crest pathway, including the forming adrenal glands, sympathetic ganglia, and some intervening cells that appear to be migrating at this stage. The presence of both brightly and weakly DiI-labelled cells in sympathetic ganglia (Fig. 2d \& e) may reflect differential cell proliferation of the implanted cells. DiI-labelled cells derived from 8 day ciliary ganglion cells were also found close to or within adrenergic structures, though their catecholamine content was not examined in detail in embryos fixed at these stages.

4-5 Days After Cell Injection. A total of ten embryos were examined at this time when transplanted cells appear to have reached their sites of localization. Transverse sections from adrenal and forelimb levels (Fig. 5a \& b) reveal a relatively mature organization of adrenergic structures in the 7.5 - 8 day host. Some Dil-labelled cells were incorporated into adrenergic structures and acquired catecholamines (Figs. 4 and $5 c \& d)$. When DiI-labelled cells were observed in sympathetic ganglia at this stage, the levels of DiI staining usually appeared low, suggesting that cell proliferation had occurred; other cells in the wall of the gut or in ectopic locations often remained brightly labelled. Sometimes clusters of bright cells could be found lateral to the sympathetic ganglia or just dorsal to the coelomic cavity (Fig. 6a); these were probably ciliary ganglion neurons that had not been incorporated into adrenergic structures. Consistent with previous grafting studies $/ 20$, we rarely observed ciliary ganglion cells in dorsal root ganglia; in the few instances where Dil-labelled cells were seen in this location, they appeared to be supportive cells rather than sensory neurons.

Dil-labelled cells derived from 6 day old 

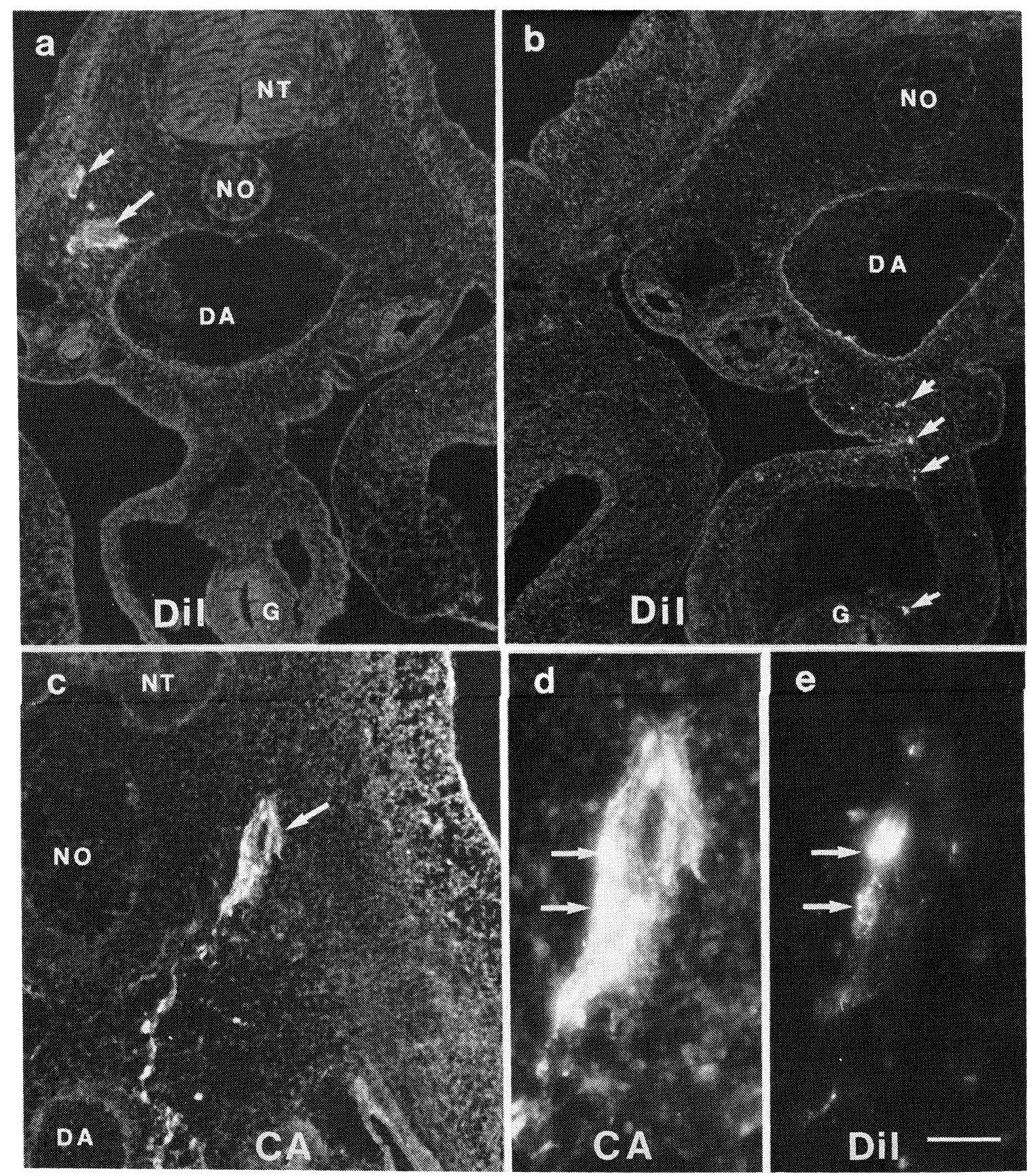

Fig. 2: Transverse sections through chick embryos after injection of Dil labelled quail ciliary ganglion cells. Embryos were fixed with an aldehyde mixture resulting in catecholamine (CA) fluorescence. a) Embryo one day after injection of 8 day ciliary ganglion cells into somites at the forelimb level; Dil labelled cell aggregates (arrows) near the injection site were clearly visible in the sclerotome lateral to the notochord and dorsal aorta. b) Embryo two days after injection of 8 day ciliary ganglion cells into somites at the forelimb level; Dil labelled cells (arrows) have moved below the dorsal aorta into the dorsal mesentery as far ventral as the gut. c) Embryo two days after injection of 6 day ciliary ganglion cells just caudal to forelimb level; catecholamine histofluorescence (violet filter) shows adrenergic cells forming a definitive sympathetic ganglion (arrow) and extending in a row ventrally toward the developing adrenal gland (see Fig. 3). d) Higher magnification of sympathetic ganglion shown in (c); arrows point to cells with catecholamine that are also labeled with Dil as shown in (e). Note that the Dil labelled cells in (e) include one that is weakly labelled and a small brightly labelled one; a larger bright cell just above the small brightly labelled one contains very little catecholamine. Bar $=100 \mu \mathrm{m}$ in a - c and $40 \mu \mathrm{m}$ in d \& e DA, dorsal aorta; G, gut; NO, notochord; NT, neural tube. 

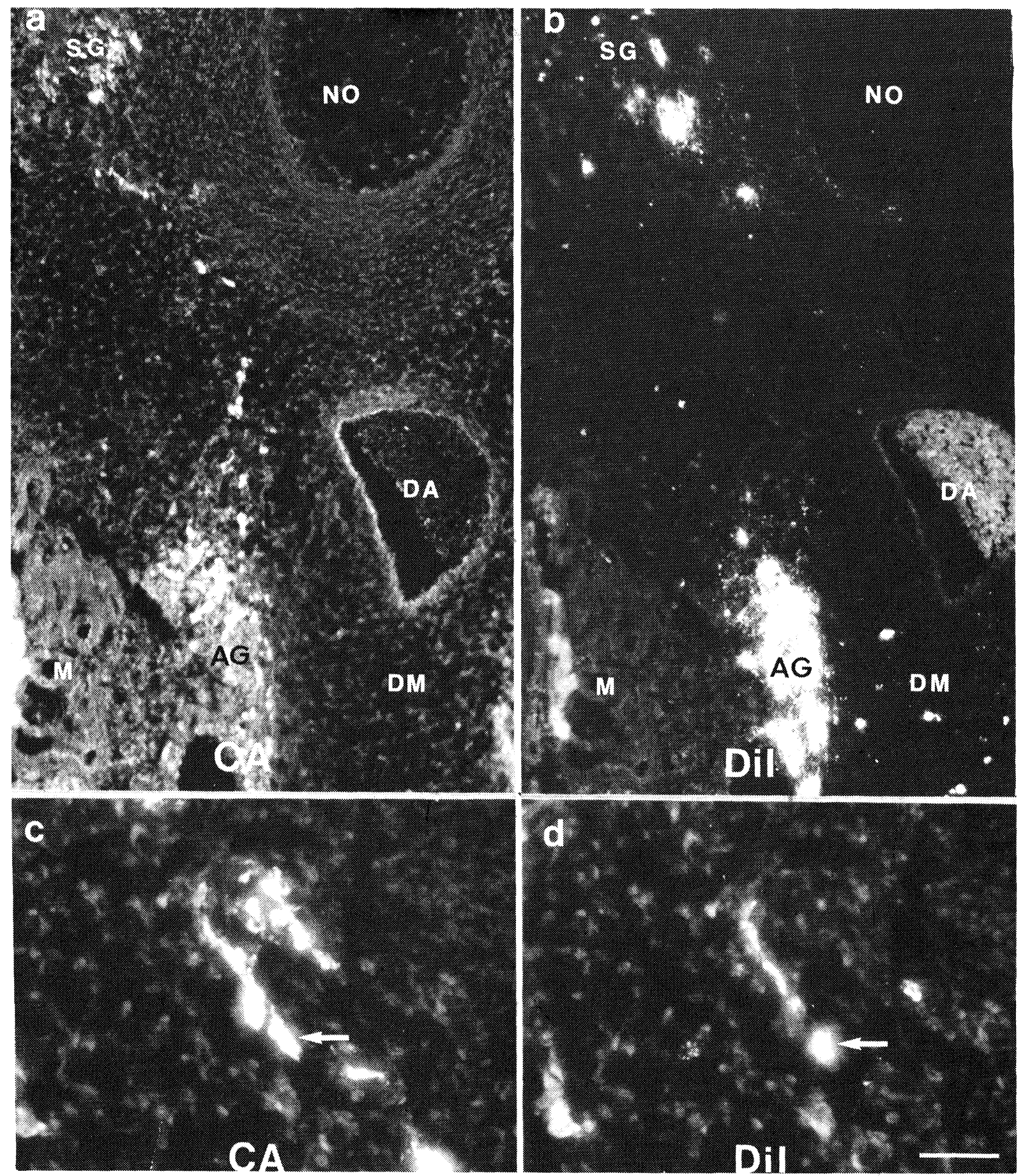

Fig. 3: Transverse sections through chick embryo 3 days after injection of Dil labelled ciliary ganglion cells from a 6 day quail embryo; the cell suspension was injected caudal to forelimb into somites $22-24$ of a 32 somite chick (comparable to embryo shown in Fig. 2C except for opposite side). a and b) Low magnification views showing catecholamine (a) and Dil (b) fluorescence at the level of the adrenal gland. Some cells in or near the sympathetic ganglion and adrenal gland contain both catecholamine and Dil; other transplanted Dil labelled cells were found in the dorsal mesentery but lack catecholamines. $c$ and d) Higher magnification of an adjacent section through the same embryo showing catecholamine positive cells ventromedial to the sympathetic ganglion; arrows indicate a cell which contains both catecholamine (c) and Dil (d). Similar catecholamine-positive cells in (a) were not Dil-labelled. Bar $=100 \mu \mathrm{m}$ in a \& b and 40 $\mu \mathrm{m}$ in $\mathrm{c} \& \mathrm{~d}$. AG, adrenal gland; DA, dorsal aorta; DM, dorsal mesentery; M, mesonephric kidney; NO, notochord; SG, sympathetic ganglion. 

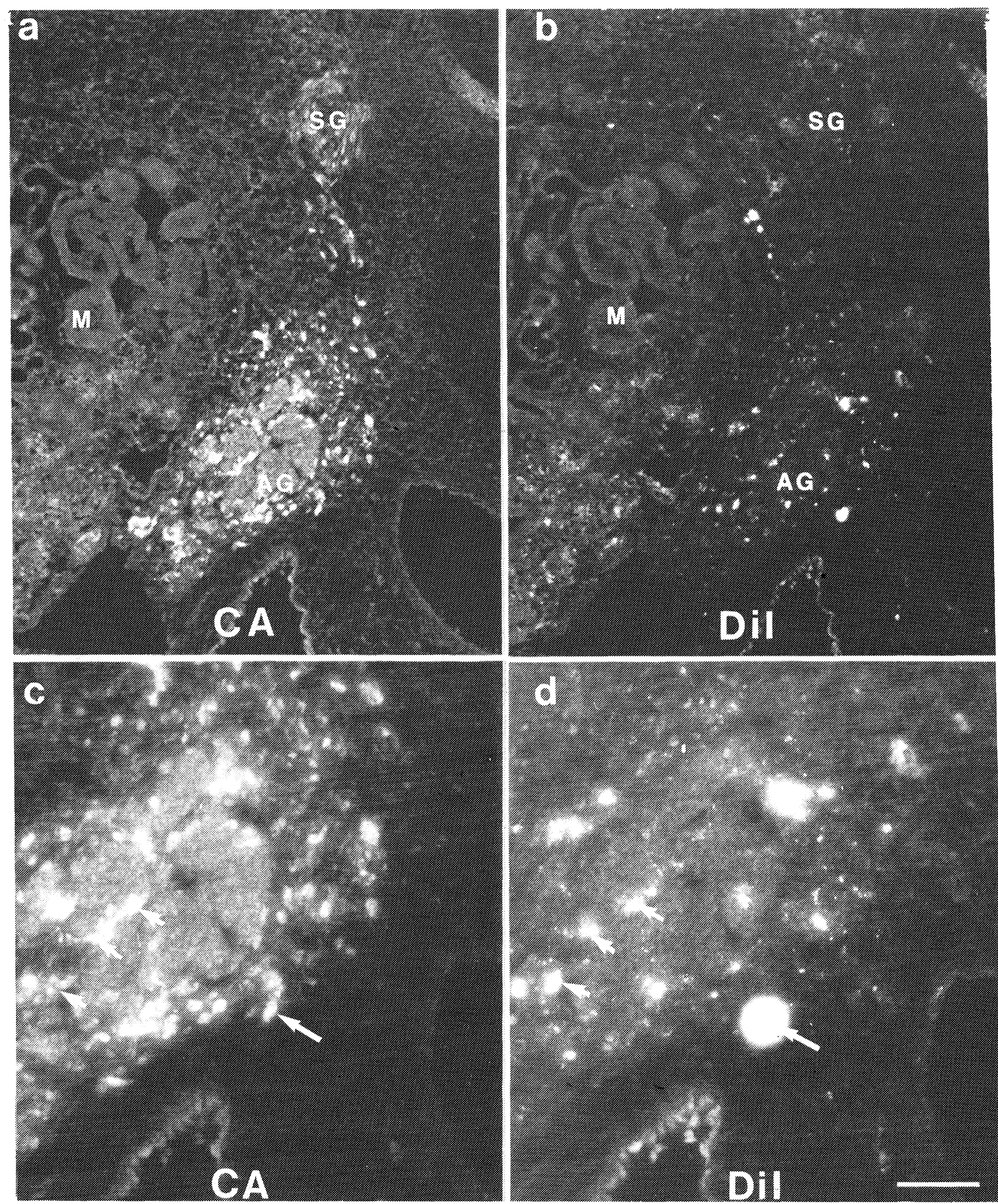

Fig. 4: Transverse section through a chick embryo 4 days after injection of Dil labelled ciliary ganglion cells from a 6 day quail embryo; the cell suspension was injected into somites $23-24$ of a 33 somite chick embyro. a and b) Low magnification views showing catecholamine and Dil fluorescence at level of the enlarging adrenal gland; most Dil labelled cells in this section are in or near the adrenal gland; in adjacent sections sympathetic ganglia may have a few cells that are usually weakly labelled with Dil. c and d) Higher magnification of the adrenal gland shows adrenomedullary cords which are catecholamine positive separated presumably by intervening corticosteroid cells which are catecholamine negative. The brightest Dil labelled cell (large arrow) on the margin of the gland is clearly catecholamine positive. Within the gland are a few less bright Dil cells (small arrows) that contain variable amounts of CA. Bar $=100 \mu \mathrm{m}$ for $\mathrm{a} \& \mathrm{~b}$ and $50 \mu \mathrm{m}$ for c \& d. AG, adrenal gland; M, mesonephric kidney; SG, sympathetic ganglion. 


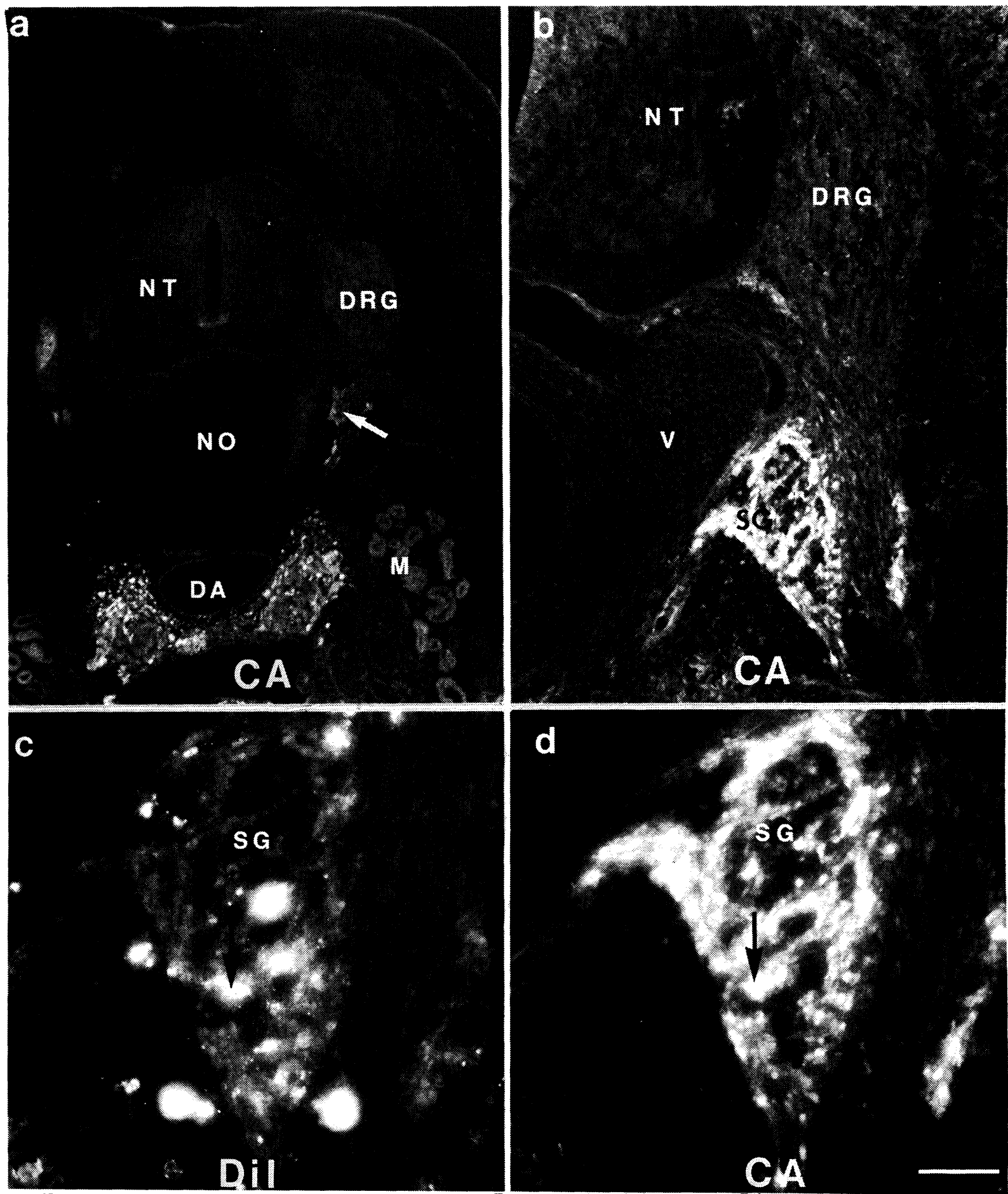

Fig. 5: Transverse sections through a chick embyro 5 days after injection of Dil labelled ciliary ganglion cells from an 8 day quail embryo; the cell suspension was injected into somite 20 of a 27 som. embryo. a) Low magnification view of section through mid-trunk showing catecholamines (CA) in cells of a sympathetic ganglion (single arrow), adrenomedullary cords and aortic plexuses ventral to the dorsal aorta. Apparent fluorescence in the mesonephric kidney is nonspecific autofluorescence. $b-d$ ) Intermediate and higher magnification views of a sympathetic ganglion at forelimb level showing catecholamine and Dil positive cells. Bright Dil labelled cells are found within and outside the ganglion only one of which was clearly catecholamine positive (arrow). In contrast, Dil-labelled ciliary ganglion cells removed from 6 day quail were much more frequently catecholamine positive (see figs. $2 \mathrm{c}-\mathrm{e}, 3$ and 4). Bar $=250 \mu \mathrm{m}$ in a, $100 \mu \mathrm{m}$ in b, and $50 \mu \mathrm{m}$ in c \& d. DA, dorsal aorta; DRG, dorsal root ganglion; $M$, mesonephric kidney; NO, notochord; NT, neural tube; SG, sympathetic ganglion; V, vertebra. 
donor ciliary ganglion cells frequently contained catecholamines in both the sympathetic ganglia and the adrenal gland (Fig. 4a-d). At 4 days postinjection, cells with both DiI and catecholamine fluorescence represented approximately 20 $25 \%$ of the incorporated labelled cells (Fig. $4 c \& d$ ) with $n=4$ embryos. The brightness of DiI labelling particularly in the sympathetic ganglia was again decreased in contrast with some bright cells in the gut wall. By 5 days after injection, there was a further reduction in the brightness of the DiI fluorescence in both sympathetic and adrenal structures, again suggesting more cell proliferation.

When transplants were derived from 8 day ciliary ganglion cells, the number of Dil-labelled cells containing catecholamines was significantly reduced compared to the 6 day ganglion transplants. Only 0 to $5 \%$ of the DiI-labelled cells in adrenergic structures also contained catecholamines ( $\mathrm{n}=6$ embryos). The example shown in Fig. 5c \& d illustrates several bright Dil-labelled cells in and around a sympathetic ganglion close to the injection site at the forelimb level of a host fixed five days after injection; only one of these cells clearly contained catecholamines. Adjacent sections through two or three ganglia revealed DiI-labelled cells with varying degrees of brightness most of which were catecholamine-negative. In more sections through this embryo, DiI-labelled cells were found in the dorsal mesentery and in the vicinity of the adrenal gland. At the level of the adrenal gland, DiI-labelled cells were often close to or among numerous catecholamine-containing cells but lacked catecholamines themselves. This observation was substantiated in a host embryo 4 days post-injection processed for catecholamines by the glyoxylic acid method. Even though there were a substantial number of DiI-labelled cells incorporated into adrenergic structures, few of these cells contained catecholamines.
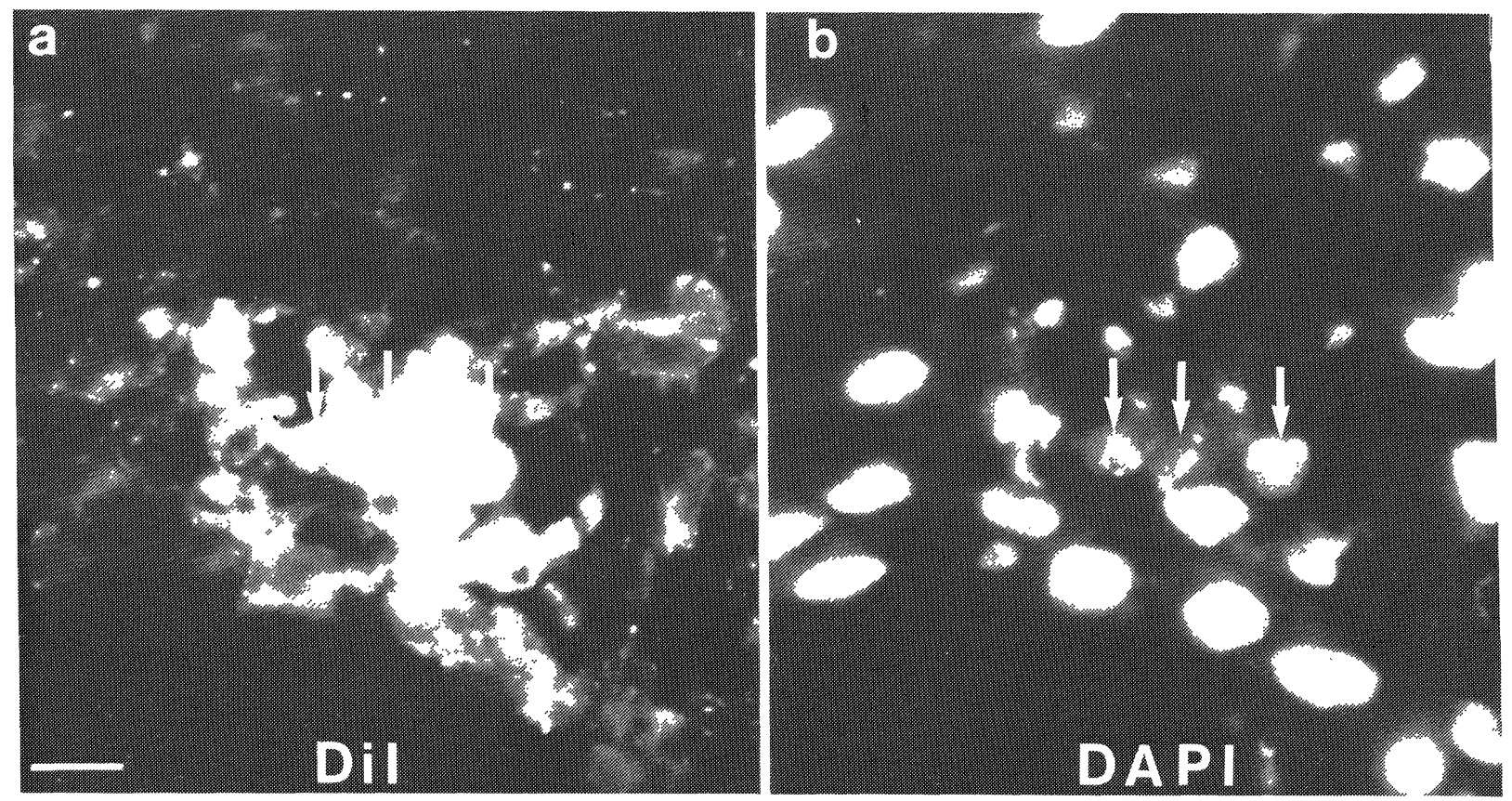

Fig. 6: High magnification of a transverse section through forelimb level of a chick embryo 5 days after injection of Dil labelled ciliary ganglion cells from an 8 day quail embryo. a) Fluorescence view (rhodamine filter) of several Dil labelled cells clustered just dorsal to the coelomic cavity and ventral to a sympathetic ganglion. b) Fluorescence view (UV filter) following the DAPI nuclear stain which shows the heterochromatin pattern of several nuclei (arrows) in the cluster to be of quail origin in contrast to the surrounding chick host nuclei which lack the large nucleolar associated DNA complex. Bars $=10 \mu \mathrm{m}$ in a \& b. 
To substantiate that the DiI-labelled cells at this stage were from quail, some sections were stained with DAPI which can distinguish quail and chick nuclei based on the appearance of DNA. Typical quail heterochromatin can be observed in a cluster of bright Dil-labelled cells (Fig. 6).

6 and 8 Days After Cell Injection. One host embryo at 6 days and another at 8 days was examined. By the sixth or eighth day post-implantation, many DiI-labelled cells could still be observed in vivo, suggesting that the dye remains detectable for long periods of time. The total number of cells appeared to be many times that of the original transplant due to extensive cell division as shown earlier in back transplants of ciliary ganglia $/ 7 /$. The labelled cells were widely dispersed including localization within somitic mesenchyme in the body wall as well as in adrenergic structures.

\section{DISCUSSION}

Our results show that DiI is an excellent marker for transplanted cells derived from the nervous system. DiI is a lipophilic vital dye that intercalates into any cell membrane with which it has contact. By labelling ganglion cells in suspension, both neurons and non-neuronal cells are well labelled both in culture (/15/; and present results), and after transplantation. Other investigators have found that topical application of DiI to neuronal precursor cells in the eyebud can be used to label retinal neurons and their projections /26,34/. Injection of Dil into the lumen of the neural tube can be used to follow the migration of neural crest cells /31/. Further DiI can be used for retrograde labelling of neuronal cells bodies $/ 15,24 /$. In confirmation of these previous studies, we find that DiI-labelled cells can be easily followed for at least 8 days after transplantation into a host embryo and that the dye remains visible through multiple cell divisions.

Dil has several advantages as a label for transplanted cells in vivo. Unlike some other vital dyes, the dye is not transferred from labelled to unlabelled cells. DiI can be observed in cultured ciliary ganglion neurons for long periods of time, suggesting it does not adversely affect cell survival $/ 15 /$. The dye labelling technique makes it possible to label cells from any species and introduce them into another or the same species, circumventing the necessity for species-specific markers. Because DiI is a membrane intercalating dye, it labels all cell membranes including neuronal processes. Therefore, it is possible to follow the early outgrowth of axons.

One disadvantage of the DiI-labelling method for dissociated cells is that by 2 or 3 days the membrane staining fades as the dye is incorporated internally in particulate form. This generally obviates the possibility of following the pattern of connectivity of transplanted neurons. However, this may not be a problem with different labelling procedures since DiI can be used to study the connectivity of individual retinal ganglion cells $/ 26 /$. Another technical problem is associated with the fact that the dye can leak from cells that are sectioned and coverslipped. However, this can be easily circumvented by storing and viewing sections without a coverslip. If it is necessary to apply a coverslip prior to photography, suitable sections should be found in advance so that coverslipping and photography can be done without delay.

An important aspect in the analysis of neural transplants is the ability to identify neurotransmitters produced by transplanted cells. Catecholamine neurotransmitters can be identified by a variety of histochemical techniques $/ 6,9,10 /$. Methods for examining formaldehyde-inducedfluorescence in tissue sections typically utilize dried sections /11/. A disadvantage of this approach is that the catecholamine histofluorescence is quenched by addition of aqueous solutions.

Using a whole mount procedure, Furness and colleagues /12/ found that catecholamines could be preserved in aqueous solution after tissue fixation with $4 \%$ paraformaldehyde and $0.5 \%$ glutaraldehyde. Using a slightly lower glutaraldehyde concentration $(0.25 \%)$, we obtained 
preservation of DiI fluorescence and fortuitously maintained catecholamine histofluorescence in the same sections. Catecholamines were readily identified in the sympathetic ganglia, adrenal medulla, aortic plexuses, and in individual cells near the dorsal aorta in embryos ranging from E4 to E8. Because there was little if any crossover between the catecholamine and DiI fluorescence, it was possible to identify cells that contained both DiI and catecholamines. The technique has the additional advantage of allowing the possibility of performing immunocytochemistry to identify other phenotypic traits of transplanted cells $/ 5,31 /$. In addition, one could carry out electron microscopic studies on the same tissue sections $/ 12 /$.

In the peripheral nervous system, there is evidence that environmental factors are important for directing neuronal differentiation. Even after overt differentiation, some autonomic neurons appear to retain a degree of phenotypic plasticity with respect to neurotransmitter synthesis. For example, cultured neurons from the superior cervical ganglion, which normally produce norepinephrine, begin producing acetylcholine in response to a factor(s) produced by non-neuronal cells /27/ or to ciliary neurotrophic factor /30/. A similar transition from adrenergic to cholinergic neurotransmitter expression has been observed in the developing sympathetic innervation to the sweat glands in the rat footpad $/ 17,18 /$. This transition is mediated by factors arising from the target tissue $/ 32 /$.

Both sympathetic and parasympathetic ganglia share a common origin in the neural crest /20/. To determine whether neurotransmitter plasticity is a common characteristic of neural crest-derived neurons, we have previously examined whether ciliary neurons undergo a cholinergic to adrenergic transition in the proper environment. When transplanted into neural crest migratory pathways at the trunk level, some ciliary neurons populated adrenergic structures and accumulated catecholamines /4/. Similar results were found earlier for a mixed population of younger ciliary ganglion cells $/ 21,23 /$. These results suggest that environmental cues influence neurotransmitter expression in the parasympathetic as well as the sympathetic nervous system. The absence of a similar complete cholinergic to adrenergic transition in tissue culture $/ 16,35$ / or after sympathectomy /1/ highlights the importance of transplantation to an in vivo environment to demonstrate neurotransmitter plasticity in some neurons.

The present experiments confirm that ciliary ganglion cells distribute widely within and beside neural crest derivatives after transplantation to the trunk region of young chick embryos. Interestingly, we find that many of the large neuronlike cells are excluded from sympathetic ganglia and the adrenal gland, though they come to lie next to these structures. This exclusion is more obvious in 8 day old ciliary ganglion transplants than in the younger 6 day ones. The results suggest that the transplanted cells from different age ganglia may respond equally to cues necessary for movement to the general vicinity of neural crest sites, but differ in their ability to become functionally incorporated.

Some of those labelled cells that became incorporated into neural crest-derived structures also produced catecholamines. Thus, the DiI-labelling did not appear to affect cell viability or the ability of the cells to migrate, differentiate and/or to have phenotypic plasticity. Ciliary ganglion cells derived from 6 day embryos acquired catecholamines significantly more frequently than ganglion cells derived from 8 day embryos. This inverse correlation between the age of ciliary ganglion cells and the ability to express catecholamines is consistent with findings of previous studies $/ 7,21,23 /$. Our present data based on a mixed cell population of post-mitotic neurons and non-neuronal cells suggests that the potential for phenotypic conversion in vivo has a limited time span for both cell populations. Even though older transplanted cells (12-15 days) may continue to be incorporated into adrenergic structures in reduced numbers $/ 7 /$, it is unlikely that ciliary ganglion cells beyond ten days of age will undergo phenotypic conversion based on the present results.

To further characterize phenotypic plasticity 
of ciliary neurons, our future experiments will couple the methodology described here with methods for producing pure populations of neurons. These techniques will allow us to further refine the range of ages of ciliary neurons capable of making the cholinergic to adrenergic transition. In addition, we will explore whether "postmitotic" ciliary ganglion cells (neurons) need to reenter the cell cycle in order to acquire catecholamines.

\section{ACKNOWLEDGEMENTS}

We thank Dr. Gabrielle Leblanc for a critical reading of the manuscript and Michael Artinger for his technical assistance. This work was supported by BNS 8809454 .

\section{REFERENCES}

1. Bjorklund $\mathrm{H}$, Hokfelt $\mathrm{T}$, Goldstein M, Terenius L, Olson L. Appearance of the noradrenergic markers tyrosine hydroxylase and neuropeptide $\mathrm{Y}$ in cholinergic nerves of the iris following sympathectomy. J Neurosci 1985; 5: 1633-1640.

2. Bronner M, Cohen A. Migratory patterns of cloned neural crest melanocytes injected into host chicken embryos. Proc Natl Acad Sci USA 1979; 76: 1843 1847.

3. Bronner-Fraser M. Transplantation by microinjection: Heterospecific analysis of avian neural crest migration and differentiation. In: Sladek J, Gash D (Eds), Neural Transplants: Development and Function. New York: Plenum Press, 1984; pp 13-42.

4. Coulombe JN, Bronner-Fraser M. Cholinergic neurones acquire adrenergic neurotransmitters when transplanted into an embryo. Nature 1986; 324: 569572.

5. Dailey ME, Bridgman PC. Dynamics of endoplasmic reticulum and other membranous organelles in growth cones of cultured neurons. J Neurosci 1989; 9: 1897-1909.

6. de la Torre JC. An improved approach to histofluorescence using the SPG method for tissue monoamines. J Neurosci Methods 1980; 3: 1-5.

7. Dupin E. Cell division in the ciliary ganglion of quail embryos in situ and after back transplantation into the neural crest migration pathways of chick embryos. Develop Biol 1984; 105: 288-299.

8. Enemar A, Falck B, Hakanson R. Observations on the appearance of norepinephrine in the sympathetic nervous system of the chick embryo. Develop Biol 1965; 11: 268-2183.

9. Eranko O. On the histochemistry of the adrenal medulla of the rat with special reference to acid phosphatase. Acta Anat (Basel) 1952: Suppl 17.

10. Falck B. Observations on the possibilities of the cellular localization of monoamines by a fluorescence method. Acta Physiol Scand 1962; 56: Supp 197.

11. Falck B, Owman C. A detailed methodological description of the fluorescence method for the cellular demonstration of biogenic amines. Acta Univ Lund 1965; II: 1-23.

12. Furness JB, Costa M, Wilson AJ. Water-stable fluorophores, produced by reaction with aldehyde solutions, for the histochemical localization of catechol- and indolethylamines. Histochemistry 1977; 52: $159-170$.

13. Hamburger V, Hamilton HL. A series of normal stages in the development of the chick embryo. J Morphol 1951; 88: 46-92.

14. Helfand SL, Smith GA, Wessels NK. Survival and development in culture of dissociated parasympathetic neurons from ciliary ganglia. Develop Biol 1976; 50: 541-547.

15. Honig MG, Hume RI. Fluorescent carbocyanine dyes allow living neurons of identical origin to be studied in longterm cultures. J Cell Biol 1980; 103: 171-187.

16. Iacovitti L, Joh TH, Albert VR, Park DH, Reis DJ, Teitelman G. Partial expression of catecholaminergic traits in cholinergic chick ciliary ganglia: Studies in vivo and in vitro. Develop Biol 1985; 110: 402-412.

17. Landis SC, Keefe D. Evidence for neurotransmitter plasticity in vivo: Developmental changes in the properties of cholinergic sympathetic neurons. Develop Biol 1983; 98: 349-372.

18. Leblanc G, Landis SC. Development of choline acetyltransferase activity in the cholinergic sympathetic innervation of sweat glands. J Neurosci 1986; 6: 146-155.

19. LeDouarin NM. A biological cell labelling technique and its use in experimental embryology. Develop Biol 1973; 30: 217-222.

20. LeDouarin NM. The Neural Crest. London: Cambridge University Press, 1982; 259 pp.

21. LeDouarin NM, Teillet MA, Ziller C, Smith J. Adrenergic differentiation of cells of the cholinergic ciliary and Remak ganglia in avian embryo after in vivo transplantation. Proc Natl Acad Sci USA 1978; 75: 2030-2034.

22. Leemann U, Ruch F. Cytofluorometric determination of DNA base content in plant nuclei and chromosomes by the fluorochromes DAPI and chromomycin A3. Exp Cell Res 1982; 140: 275-282.

23. LeLièvre CS, Schweiger GG, Ziller CM, LeDouarin NM. Restrictions of developmental capabilities in neural crest cell derivatives as tested by in vivo transplantation experiments. Develop Biol 1980; 77: 362378. 
24. Lumsden A, Keynes R. Segmental patterns of neuronal development in the chick hindbrain. Nature 1989; 337: 424-428.

25. Nishi R, Berg DK. Dissociated ciliary ganglion neurons in vitro: Survival and synapse formation. Proc Natl Acad Sci USA 1977; 74: 5171-5175.

26. O'Rourke NA, Fraser SE. Gradual appearance of a regulated retinotectal projection pattern in Xenopus laevis. Develop Biol 1989; 132: 251-265.

27. Patterson PH, Chun LLY. The influence of non-neuronal cells on catecholamine and acetylcholine synthesis and accumulation in cultures of dissociated neurons. Proc Natl Acad Sci USA 1974; 71: 36073610.

28. Rohrer H, Thoenen $\mathrm{H}$. Relationship between differentiation and terminal mitosis: Chick sensory and ciliary neurons differentiate after terminal mitosis of precursor cells, whereas sympathetic neurons continue to divide after differentiation. J Neurosci 1987; 7: 3739-3748.

29. Rothman TP, Gershon MD, Holtzer H. The relationship of cell division to the acquisition of adrenergic characteristics by developing sympathetic ganglion cell precursors. Develop Biol 1978; 65: 322-341.

30. Saadat S, Sendtner M, Rohrer H. Ciliary neurotrophic factor induces cholinergic differentiation of rat sympathetic neurons in culture. J Cell Biol 1989; 108: 1707-1816.

31. Serbedzija GN, Bronner-Fraser M, Fraser SE. A vital dye analysis of the timing and pathways of avian trunk neural crest cell migration. Development 1989; 106: 809-816.

32. Schotzinger RJ, Landis SC. Cholinergic phenotype developed by noradrenergic sympathetic neurons after innervation of a novel cholinergic target tissue in vivo. Nature 1988; 335: 637-639.

33. Sladek J, Gash D (Eds), Neural Transplants: Development and Function. New York: Plenum Press, 1984; 454 pp.

34. Stuermer CAO. Retinotopic organization of the developing retinotectal projection in the zebrafish embryo. J Neurosci 1988; 8: 4513-4530.

35. Teitelman G, Joh TH, Grayson L, Park DH, Reis DJ, Iacovitti L. Cholinergic neurons of the chick ciliary ganglia express adrenergic traits in vivo and in vitro. J Neurosci 1985; 5: 29-39.

36. Varon S, Manthorpe M, Adler R. Cholinergic neuronotrophic factors: 1. Survival, neurite outgrowth and choline acetyltransferase activity in monolayer cultures from chick embryo ciliary ganglia. Brain Res 1979; 173: 29-45. 

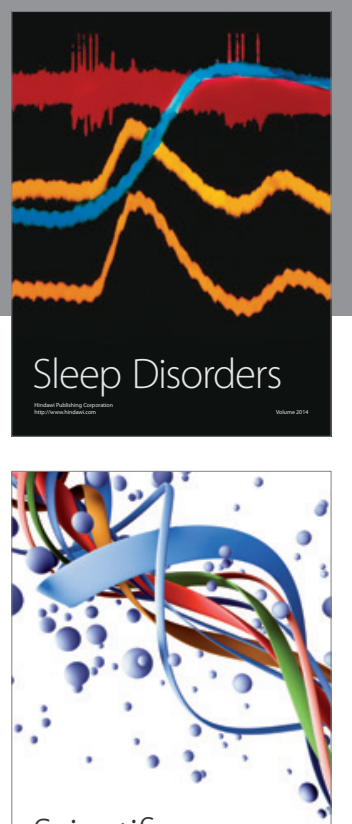

Scientifica
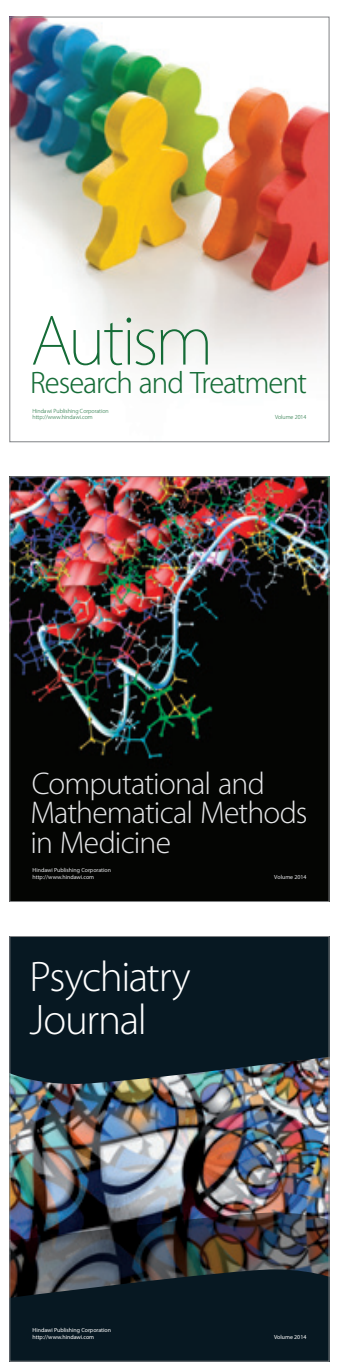
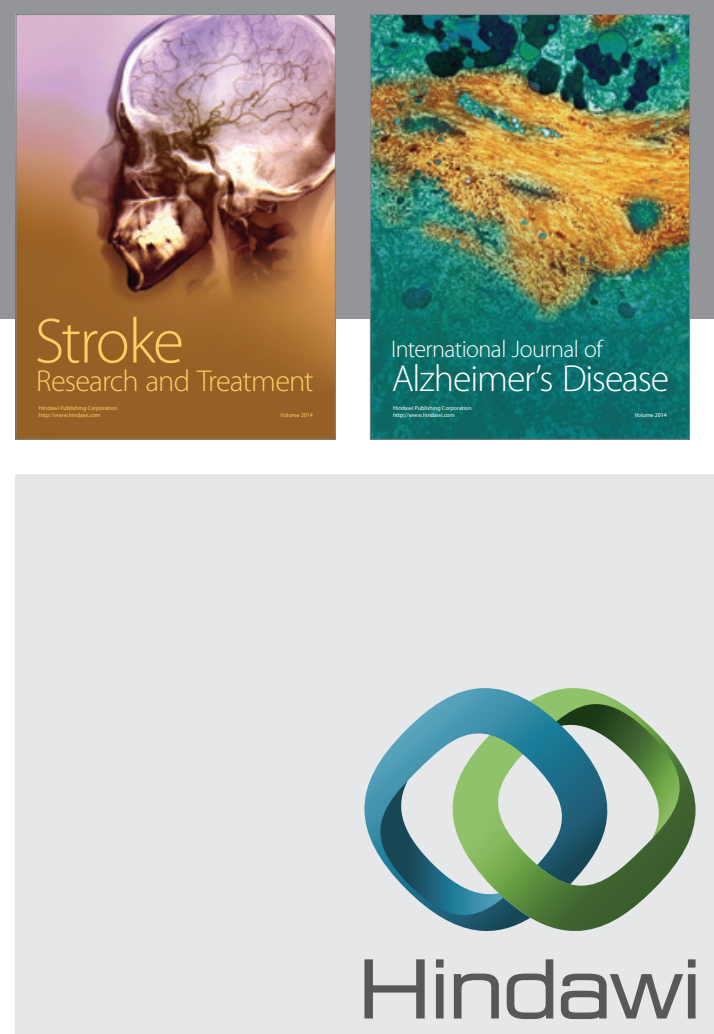

Submit your manuscripts at

http://www.hindawi.com
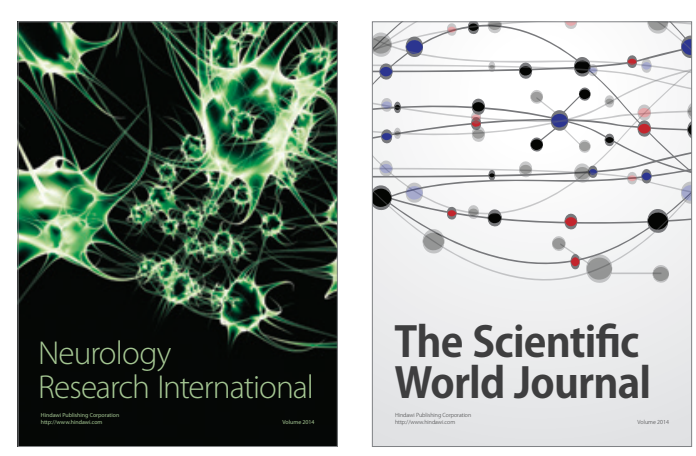

The Scientific World Journal

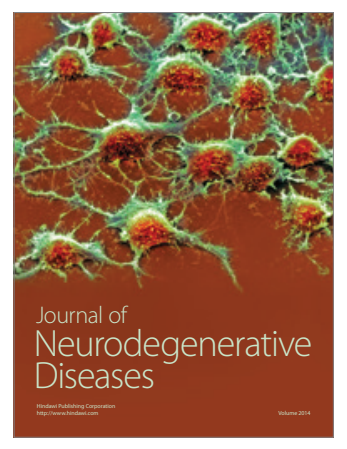

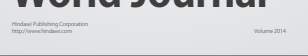

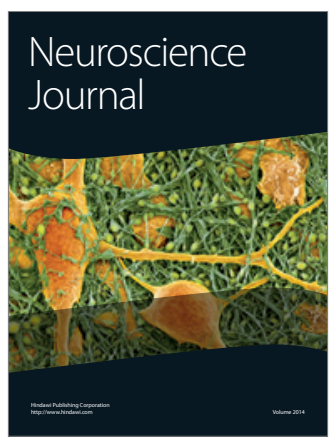

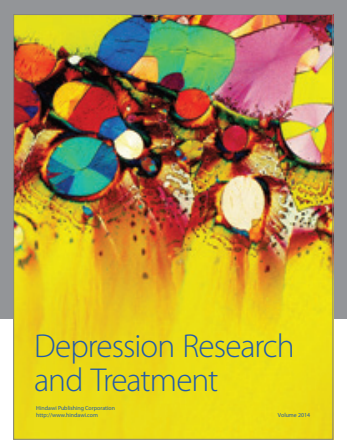
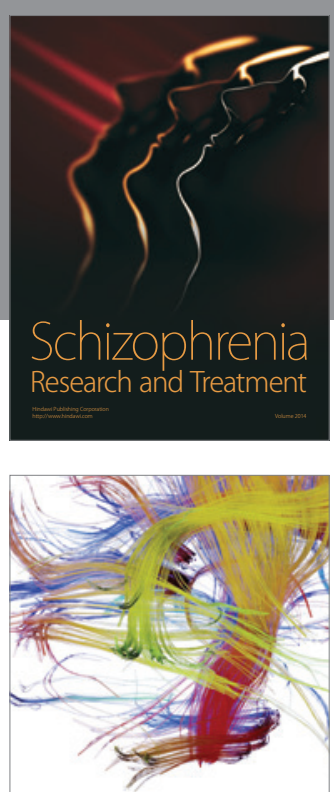

Brain Science

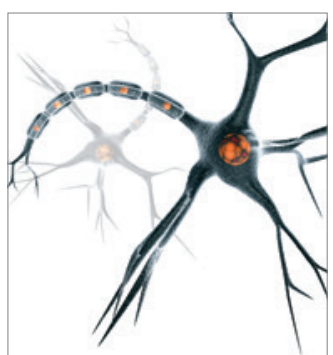

Neural Plasticity
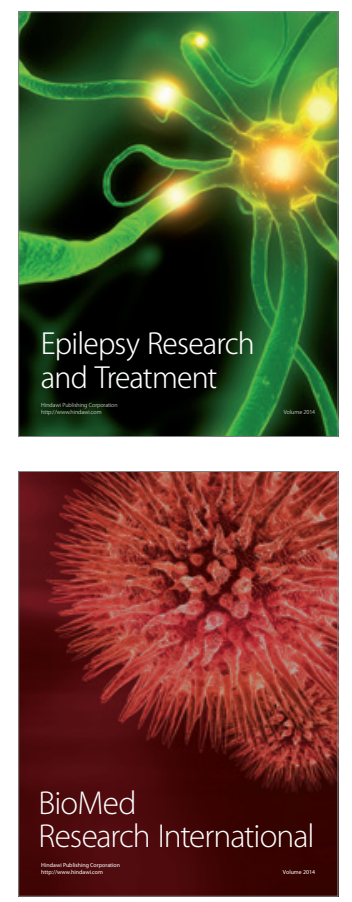

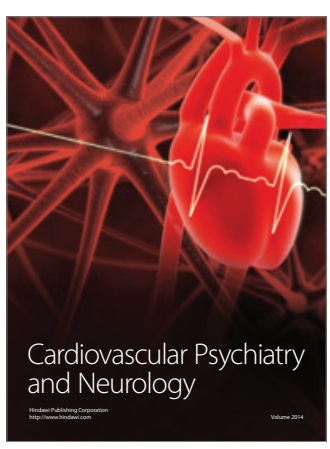

Parkinson's

Disease
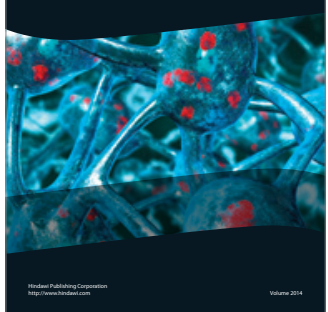